\author{
Dariusz KIEŁCZEWSKI, PhD, Professor University of Bialystok \\ Faculty of Economics and Finance, University of Bialystok \\ e-mail: d.kielczewski@uwb.edu.pl \\ ORCID: 0000-0001-9801-909X
}

DOI: $10.15290 /$ oes.2020.02.100.09

\title{
MAINSTREAM ECONOMICS VERSUS HETERODOX ECONOMICS - BETWEEN DISPUTE AND DIALOGUE ${ }^{1}$
}

\begin{abstract}
Summary
Purpose - The purpose of this article is to highlight the differences between mainstream and heterodox economics and essence of the dispute between them, as well as to indicate that this dispute results from attachment to a reductionist Cartesian research approach.

Research method - The work utilises a review and analysis of the literature on the subject, deductive and inductive inference, as well as a linguistic descriptive method and tabular summaries.

Results - The author concludes that the contemporary discussion between economic trends can be reduced to a confrontation of two reductionisms in the perception of economics: individualistic and objective, as well as social and normative. Breaking this methodological limitation provides an opportunity to search for pluralistic (integrated) economic positions in the future.

Originality / value / implications / recommendations - Awareness of methodological aspects of the dispute between economic trends. Indication of the possibility of building pluralistic and integrated positions. Usefulness in building economic theory. Awareness of the need for diversity in economic research.
\end{abstract}

Keywords: mainstream economics, heterodox economics, reductionism, pluralism

JEL Classification: B4, B5

\section{Introduction}

The economic decline observed at the turn of decades triggered a lively discussion on the subject of economics and its application. Among many reasons, it was related to the fact that few specialists associated with mainstream economics could predict the recession phenomena observed during the late 2000s and early 2010s in comparison with alternative economists representing various schools collectively referred to as "heterodox economics". The Bezemer's [2009] list includes the names of twelve economists who predicted this economic decline. Eight of them are representatives of the post-Keynesian schools of thought, such as that of Keen, Roubini,

\footnotetext{
${ }^{1}$ Article received on 20 January 2020, accepted on 23 February 2020.
} 
Madsen, and particularly that of the Austrian economist Richebacher. It has also been confirmed by the studies conducted by Fullbrook [2009] who strongly underlines the fact that non-mainstream economists (mainly post-Keynesian, for example Keen and Lawson) were more accurate to assess the risk of recession. In addition, it has been pointed out that the recession was the effect of the implementation of the mainstream formulas for economic policy and was an outcome of the very essence of the dominating economic paradigm [Krugman, 2009; Kraciuk, 2015, pp. 222-225; Sedlacek, 2012b]. The purpose of this article is to present differences in the research approaches to economics of both schools of thought and to indicate that the current dispute results partially from a traditional reductionist (Cartesian) approach to this field of science. If the dispute is overcome, then it will create an opportunity for economics to open up for developing pluralistic approaches, internally diversified, or integrated, and thus more realistic.

\section{Methods of economics - a need for reflection}

The goal of economics as a science is to develop a reliable, verifiable, repeatable and unquestionable way of validating knowledge about the economy. Most economic textbooks or journals suggest that it is a homogenous science, whose subject and method have been clearly, strictly and precisely defined ${ }^{2}$. However, trying to validate knowledge in any field requires certain preliminary assumptions to define the principles of reaching the most reliable model of knowledge validation. In the case of economics, the questions are as follows:

- what is the subject of economics and what is the nature of economic terms; is the goal to study the economic regularities or perhaps the purpose is to analyse the ways of getting rich [Mill, 1965], searching for wealth and happiness [Davis, 2015], developing a better society [Robinson, 2016], satisfying needs in the context of goods scarcity [Wilkin, 2009, s. 295-313],

- $\quad$ who is the economic subject [Grzesiuk, 2014, pp. 253-286],

- what is the role of economics in the system of science; in particular, how economics as a social science refers to other disciplines defined as exact science, that is formal and natural sciences (should it be its analogon, or should it be explicitly separate and distinct from them), and therefore, what is the method of economics, that is the right and reliable way of recognising economic entities, as well as limits of such recognition.

- $\quad$ is there any place in economics for axiology and appraisal, or whether it should be science which is neutral and objective.

- $\quad$ is there any universal economic model relevant for each economic system?

\footnotetext{
2 In the foreword to the book "Rethinking Economics" it has been expressed in the following way: "Each day, as the economy disintegrated, we would open our textbooks to gracefully shifting supply and demand curves... economics was presented as a placid, settled subject, with physics-like laws that kept everything operating in perfect order." [Pomyśléc..., 2018, p. 23].
} 
- how to conduct economic research and avoid mistakes related to its procedures and implementation of research results [Blaug, 1995, pp. 15-18; Gorazda, 2013; Gorynia, 2019; Kiełczewski, 2009; Wojtyna, 2000, p. 12; Wojtyna, 2019].

Economists have provided various answers to all these questions. In this way, groups of axioms (that is sets of fundamental and by principle unquestionable statements according to which individual models of validating economic knowledge) have been developed. As a result, research approaches are diversified, which in turn leads to diversified theoretical concepts proposed within individual trends of economics. According to the basic assumptions and increasingly precise analysis of economic processes, they propose different visions of reaching the economic truth, and they also interpret and predict economic phenomena differently (table 1).

\section{Differences in the research approach of economists}

TABLE 1

\begin{tabular}{|l|l|}
\hline \multicolumn{1}{|c|}{$\begin{array}{c}\text { Research } \\
\text { dimension }\end{array}$} & \multicolumn{1}{c|}{ Diversity of research approach } \\
\hline $\begin{array}{l}\text { Substance } \\
\text { of economics }\end{array}$ & $\begin{array}{l}\text { - economics as a "pure" science, separate from other fields of science } \\
- \text { economics as a science using achievements and methods of other fields } \\
\text { of science, which accepts interdisciplinary research }\end{array}$ \\
\hline $\begin{array}{l}\text { Substance } \\
\text { of economic } \\
\text { entities }\end{array}$ & $\begin{array}{l}\text { - individualism: economic entities result from human nature } \\
\text { - universalism: economic entities are common economic laws } \\
- \text { biologism: economic entities are the product of evolution and they } \\
\text { change along with people } \\
- \text { neutralism: focusing on real economic laws and dependencies due to the } \\
\text { relative nature of economic entities and their definition (therefore } \\
\text { underdetermined and ambiguous) }\end{array}$ \\
\hline $\begin{array}{l}\text { Axiology in } \\
\text { economics }\end{array}$ & $\begin{array}{l}\text { economics as a moral science } \\
- \text { economics as an objective science } \\
\text { economics as an objective (positive) and normative (dualistic approach) } \\
\text { science } \\
- \text { economics and an intersubjective science } \\
- \text { economics as subjective narration }\end{array}$ \\
\hline
\end{tabular}

Source: own elaboration.

As a result of the diversification of answers, and therefore of economic theories, as well as their hierarchy, some of them become the mainstream. The others constitute the heterodoxy, which means that they are considered as trends without any major significance or they are refused the status of science. Nowadays, there are several ways of pursuing economics:

- economics as a science which is objective, mechanistic, monistic and mathematicised, which methodology should be searched for in Popperism, Williamson's operationalism, Friedman's instrumentalism, and the develop- 
ment of econometrics; that is in investigations originating from the Cartesian approach, positivism and neopositivism,

- $\quad$ economics as a science representing new monism, looking for its methodology foundations in the systemic and holistic approach and based on new physics, ecology, deterministic chaos and evolution theories,

- $\quad$ economics as a political and normative science, post-Marxian or post-Keynesian,

- economics as a science using achievements of other social sciences, i.e. sociology, psychology, but also philosophy or history,

- economics as a science studying the impact of institutions on the functioning of economic systems,

- $\quad$ economics as a collection of narrations representing the opinions of economists only (postmodern approach).

However, such richness has not been reflected to date in present-day science and the teaching of economics.

\section{Differences in the mainstream and heterodox economics}

Contemporary economics has been dominated by an approach originating from neopositivism, operationism and instrumentalism. It is believed that it also includes theories which accept individualism, optimisation, economic equilibrium, abstractive formalised and objective approach, and attachment to economic growth and the concept of homo economicus [Pomyślé́..., 2018; Czaja et al., 2012, p. 141; Fiedor, 2019]. These are trends originating from neoclassical economics. Contrary to the clearly defined mainstream economics, heterodox economics is not explicitly classified, except for the common agreement that it is a collection of alternatives for the mainstream economics. Colander et al. [2004] divides it into two general groups:

1. inward directed, aiming at reforming and completing the mainstream economics to make it more realistic; he includes in this group New Institutionalists, Austrians, behavioural economics, experimental economics and complexity economics,

2. outward directed, radical, whose representatives do not see any option for reforming the mainstream economics, and in exchange they propose creation and development of an academic opposition and alternative for it: radical economics (post-Marxism), feminist economics, ecological economics, postKeynesian economics and neo-institutionalism.

The authors who clearly identify themselves with heterodox economics, usually call themselves as the representatives of the outward directed movement. There is a significant example of a discussion around Colander's [2009] statement, that the traditional "mainstream" does not exist anymore, since it has been replaced with the "new mainstream", which accepts the main assumptions of the heterodox trends. Kvangraven and Alves [2019] observe that the mainstream economists in fact raise issues which were previously reserved for heterodox economists. However, they 
stress that usually it is just admitting that some factors were underestimated or ignored by them upon any attempt of "framing" them in terms of those approaches. Stillwell [2006] defines it straightforwardly as fake diversity of the mainstream economics, while he stays with the old strictly interpreted assumptions of individualism, equilibrium and rationalism of the market. Therefore, it is not an acceptance of heterodoxy, but a consolidation of the mainstream domination, leading to even stronger marginalisation of the non-orthodox trends in economics.

Lee [2009] and Lawson [2006] formulated definitions of the heterodox economics which have been so far deemed as the most influential. Lee describes the heterodox economics theory as "the empirically grounded theoretical explanation of the historical process of social provisioning in the context of capitalist economy" [quoted after Stillwell, 2019, pp. 8-9]. In heterodoxy, the point is to provide for a fair distribution of wealth and investigating which conditions should be fulfilled by capitalism to make it possible. It promotes practicing economics in the pluralistic and integrated way based on the principle of responsibility and intellectual openness of the researchers. Thanks to that, it is possible to examine more deeply and raise the issues of class, gender, institution, market instability, insecurity, exploitation, political inequality, distribution conflicts and environmental challenges.

TABLE 2

\section{Heterodoxy versus mainstream economics}

\begin{tabular}{|l|l|l|}
\hline \multicolumn{1}{|c|}{ Criterion } & \multicolumn{1}{|c|}{ Orthodoxy } & \multicolumn{1}{c|}{ Heterodoxy } \\
\hline $\begin{array}{l}\text { Approach to social } \\
\text { reality }\end{array}$ & $\begin{array}{l}\text { Closed } \\
\text { Rational agents with access to } \\
\text { information }\end{array}$ & $\begin{array}{l}\text { Open } \\
\text { Heterogeneous, holistic, } \\
\text { institutional agents }\end{array}$ \\
\hline Economics & Deduction (axioms) & $\begin{array}{l}\text { Social construct with a } \\
\text { historical overtone }\end{array}$ \\
\hline Norms & Utilitarian ethics (V. Pareto) & Social ethics (I. Kant) \\
\hline Methodology & $\begin{array}{l}\text { Individualism (marginalism), } \\
\text { mechanistic monism }\end{array}$ & $\begin{array}{l}\text { Methodological pluralism, } \\
\text { holism (systemism) }\end{array}$ \\
\hline Basis & $\begin{array}{l}\text { Monetary dimension, } \\
\text { equilibrium model }\end{array}$ & $\begin{array}{l}\text { Pluralism, cyclicity, relations } \\
\text { Subject of interest }\end{array}$ \\
Capitalists and managers & $\begin{array}{l}\text { Focus on less privileged social } \\
\text { groups, or even non-human } \\
\text { beings }\end{array}$ \\
\hline Research basis & $\begin{array}{l}\text { Objective economics without } \\
\text { appraisal }\end{array}$ & $\begin{array}{l}\text { Conviction that each } \\
\text { economic theory comprises } \\
\text { valuation elements }\end{array}$ \\
\hline Language & $\begin{array}{l}\text { Mathematicised language } \\
\text { dominates }\end{array}$ & $\begin{array}{l}\text { Scientific descriptive, with } \\
\text { elements of colloquial } \\
\text { language }\end{array}$ \\
\hline
\end{tabular}

Source: amended after: [Rogowska, 2016, pp. 111-112]. 
According to Lawson [2006], the essence of heterodox economics is pluralism combined with methodological openness based on including connections between economic phenomena and the holistic approach in opposition to the mainstream economics based on deductivism, mathematical modelling, and constructing "hard" correlations and "objective" regularities. Therefore, both Lee [2009] and Lawson [2006] contrast mainstream and heterodoxy, attributing hermetic and rigid assumptions, as well as being stuck in scientific abstraction to the former, while the latter is described with methodological openness and resolution of genuine economic problems. Nowadays, within the heterodoxy itself there is a dominating radical approach, which is suspicious even towards trends which are relatively close to mainstream economics. Thus, a tendency to a'rebois reductionism can be observed. For example, Keen [2019] openly calls to rejecting the neoclassical tradition, which in his opinion cannot be saved. Table 2 presents Kapp's correlations of profound differences between the trends. Undoubtedly, they are significant and hinder dialogue. The classification developed by Kapp has been slightly modernised by the author of this article by completing it with differences omitted in the original comparison.

The fact that such differences exist induce an attempt to answer the question about the future of economics: continued domination of the mainstream trend, coexistence of different approaches similarly to other social sciences, or perhaps the dominance of the new approach.

\section{Prospects for the future - dispute or dialogue?}

In literature, it has been possible so far to notice a clear animosity among economists identifying themselves with the described schools of economics, which is manifested in mutual criticism. Radical heterodox economists severely criticised the mainstream economics on the occasion of the recession from the turn of decades. Orrell [2017] and Keen [2019] almost totally reject the fundamental principles of mainstream economics. Orrell identifies it with mythology, not science, by comparing the neoclassical economics with Pythagoras' mathematical fiction. Keen predicates its fiasco and a need to reject it. Furthermore, Sedlacek [2012a] faults mainstream economics claiming that it distorts the essence of economics. By bringing it down to quantitative methods, it corrupts and compromises its substance. Throughout history, people have always considered the question of how to satisfy their unlimited needs while having limited resources at their disposal, and also which ways of satisfying such needs are correct, and which are not, or - as this author puts is straightforwardly - which are good, and which are bad. Mathematicised economics deprives those who apply it of any ethical brakes and makes them lose sight of a human being in favour of numbers. Nowadays, it turns them towards collecting assets and speculating on the stock market instead of taking care of the common social interest. Perhaps, such phenomena occurred because economists at universities are not taught how to be human beings, but they are taught how to maximise profits or investment return rates while ignoring the ethical aspect. Czaja at al. 
[2012, p. 28] suggest that modern economics resembles more a sophisticated logical game than social science. Zabkowicz [2019, pp. 3-4] asks directly whether the economics of capitalism exists at all.

Stilwell [2019] states that between two trends in economics there are not any points of tangency. In such a situation, the key task of heterodoxy economics is to create an alternative for mainstream economics, however, it is possible exclusively in the cooperation with sociologists, political scientists, feminists, environmentalists, geographers, or historians, as a peculiar rebellion against the domination of the main trend. There are no workable possibilities of cooperation with mainstream economics, since its representatives imposed their narration to everybody; they dominated all research institutes and academic centres by gradually eliminating all considerations from the perimeters of the mainstream economics. Their domination extended to scientific economic magazines which commonly consider only mathematicised economics as scientific (even mathematicised history of economics in place of "traditional" one), and also to the system of financing scientific research and didactics in economics [Stilwell, 2019; Lee, 2009]. Therefore, it is necessary to focus on creating alliances with representatives of other social sciences and humanities, education for adults and establishing lobby groups to achieve gradually further advantages in the academic system. It corresponds to the reflection expressed by Ząbkowicz [2019, p. 15]: "perhaps economists should more often establish cooperation with sociologists, political scientists, lawyers and historians, and focus less on setting the perimeter of the identity of economics?". Therefore, it seems that the intention of heterodox economists is to replace the objective neoliberal and neoclassical approach with normative political economy (among radicals) or at least conduct a through reform primarily based on the approach of the new institutional economics thus acknowledged as the new paradigm according to Kuhnian theory [Godłów- Legiędź, 2010; Ząbkowicz, 2019, pp. 3-15].

However, numerous mainstream economists do not see any possibility for the cooperation with economists proposing various alternatives. For example, Wells [2010] writes about heterodox economics with an ostentatious disregard pointing out that it is absent in academic journals or at leading universities. He further argues that it constitutes a collection of incoherent ideas making references to old theories which were proven falsifiable long ago. Allegedly, scientists from this group do not have the opportunity for a serious academic career since they cannot use specialised mathematicised language of economics and they are not able to meet the requirement of elementary skills expected from an economic researcher. As a result, they are pushed aside to the departments of sociology or geography and complain about being misunderstood and suspect an establishment conspiracy against their outstanding discoveries. The author concludes that their findings might be useful, but first they would need to be written down in precise mathematicised formulas which is appropriate for economists.

Therefore, it can be observed that there is high tension between these two trends of economics. Their respective representatives predominantly focus on justifying their own approaches while questioning or even ignoring alternative ideas. Horo- 
decka [2019] notices that the influence of the institutional system in science has so far favoured mainstream economics. She is correct, however, the author of this article points here to methodological reasons. The dispute may be presented as a confrontation of the opposite reductionist approaches bringing the object of research to simplified unquestionable statements which may be deemed as axioms. On the one hand, we deal with objective, formalised and abstract reductionism based on limiting economics to the world of numbers and models, and the bomo economicus to an egoist guided by economic rationalism, ignoring the social and axiological context of economy. On the other hand, despite methodological declarations, we deal with an approach that is equally reductionist (normative and postulative), a wish to implement idealised concepts of human nature and economy resistant to occurrence of crisis situations, and an assumption about the individual and objective contexts of market operation. It is not clear why so many heterodox economists so openly reject mainstream economics [Keen, 2019; Orrell, 2017; Sedlacek, 2012a], since almost everybody demands pluralism in research in economics, and numerous achievements of mainstream economics are unquestionable. It seems that previously it was understood as a freedom of choice of the research method to study economic phenomena and equal polemic, instead of searching for joint research planes. Perhaps, such a great distance is the result of the popularisation of the Lakatos' methodological concepts, whose idea of a competition of scientific research programmes, particularly in the Anglo-Saxon economics, were interpreted literally as an absolute market fight. Where Lakatos expected an open discourse, a situation occurred where one trend dominated all others and pushed them to the margin, thus becoming the only paradigm.

In that context it is worthwhile to refer to the approach of Polish authors, who have not been under such a great influence of the Lakatosian "war" of research programmes. They notice points of tangency and a field for dialogue in this dispute. Fiedor, Gorynia [2019] acknowledge the modern discourse as a strength of economics since it creates an opportunity for a wide spectrum of an analysis of contemporary problems thanks to including the diversity of research perspectives (from global to microeconomic), behaviour of suppliers and consumers, research methods and many other elements [Fiedor, 2019, pp. 45-56].

Searching for ways combining both approaches, according to the holistic or systemic approaches declared by many heterodox economists, seems to be the right and desired solution. Both trends focus on different dimensions of the economy functioning and only after they are inter-connected as an integrated whole, they could give a complete image of economic phenomena. Mainstream economics is focused on an individual approach, quantitative, growth-promoting, equilibrium and the concept of a man who is economically rational. Heterodox economics studies any deviations from that model and suggests which actions may be taken, when the mainstream instruments do not work in critical situations, causing negative social and economic consequences or economic recessions. It also underlines that a man is not really homo oeconomicus, but homo diversificatus. People possess numerous motivations when taking economic decisions. It is not possible to bring down their beha- 
viour to exclusively economic (bomo oeconomicus), idealistic (such as homo sustinens) or pro-social (bomo socjologicus) motivation. Other important factors include opportunism, conformism, or an intention to stand out. Such various motivations should be considered at least in designing economic policies. ${ }^{3}$ It is a good starting point to create new pluralistic economic concepts. According to the author, the entry stage for such creation is to acknowledge that the approaches represented by both schools are not antinomy, but they are complementary. Pluralism understood in such a way combined with a gradual integration of economics as a science would allow for a more detailed investigation of what is the subject of that science, an analysis of various economy configurations, and searching for ways of an improved functioning of real economics. To achieve that, it is necessary to overcome reductionistic and competitive thinking, as well as the habitual thinking that theories are research approaches which fight with each another or are mutually excluding alternatives.

\section{Conclusions}

According to many authors [Galbraith, 1973], economics is the only social science where only one doctrine has so strongly dominated the scientific research. It is an unfavourable situation, since it relates to a strict methodological framework considerably limiting the dynamics of research in this field; the economic recession caused a revival and initiated a discourse which blew the framework apart. Several alternative trends seem to have permanently entered mainstream economic considerations. An important place belongs to the new institutional economics, behavioural economics, experimental economics and complexity economics. Other trends are currently not very popular, which seems to be an unfavourable situation since they contain inspiring proposals of resolving present-day economic problems, with which mainstream economics cannot cope. However, their utilisation depends on whether the discussion is still going to be conducted on the principle of the competition of opposite approaches, or perhaps the dialogue may gradually lead to form a new concept of economics or meta-economics integrating various research approaches. According to the author of this article, the latter solution seems to be more justified, however it requires a change in the research routines and habits.

\section{References}

Bezemer D., 2009, No One Saw This Coming. Understanding financial crisis through accounting models, „SOM Research Reports”, vol. 09002.

Blaug M., 1995, Metodologia ekonomii, PWN, Warszawa.

${ }^{3}$ Homo diversificatus is the term proposed by the author of this article. 
Colander D., 2009, Moving Beyond the Rhetoric of Pluralism: Suggestions for an 'Inside the Mainstream' Heterodoxy, [in:] Economic Pluralism, Garnett R., Olsen E.K., Starr M. (ed.), Routledge, London and New York.

Colander D., Holt R., Rosser Jr B., 2004, The changing face of mainstream economics, "Review of Political Economy", vol. 16(4), pp. 485-499, DOI: 10.1080/09538 25042000256702.

Czaja S., Becla A., Włodarczyk J., Poskrobko T., 2012, Wyzwania wspótczesnej ekonomii. Wybrane problemy, Difin, Warszawa.

Fiedor B., 2019, Podziat na ortodoksje $i$ heterodoksje w śnietle potrzeby pluralizmu metodologicznego w ekonomii, perspektywa mikroekonomiczna, [w:] Ewolucja nauk ekonomicznych. Jedność a różnorodność, relacje do innych nauk, problemy kelasyfikacyjne, Gorynia M. (red.), PAN, Warszawa.

Fiedor B., Gorynia M., 2019, O silnych i stabych stronach wspótczesnych nauk ekonomicznych, „Biuletyn Polskiego Towarzystwa Ekonomicznego”, nr 4(87), s. 13-20.

Fullbrook E., 2009, Ontology and Economics. Tony Lawson and his Grotics, Routledge, London- New York.

Galbraith J.K., 1973, Power and the Useful Economist, "American Economic Review", vol. 63(1), pp. 1-11.

Godłów- Legiędź J., 2010, Wspótczeesna ekonomia: ku nowego paradygmatowi?, C.H.Beck, Warszawa.

Gorazda M., 2013, Filozofia ekonomii, Copernicus Center Press, Kraków.

Gorynia M., 2019, Wspótczesne nanki ekonomicz̨ne - tożsamość, ewolucja, klasyfikacje, [w:] Ewolucja nauk ekonomicznych. Jedność a różnorodność, relacje do innych nauk, problemy klasyfikacyjne, Gorynia M. (red.), PAN, Warszawa.

Grzesiuk K., 2014, Ponstanie $i$ ewolucja modelu homo economicus, „Roczniki Ekonomii i Zarządzania", t. 6(42), nr 2, s. 253-288.

Horodecka A., 2019, Podzialy miedzy ekonomia ortodoksyjna a heterodoksyjna: źródta, rodzaje $i$ aspekty a rozwój ekonomii, https://kongresekonomistow.pl/materialy-kongresowe/_/attachment/inline/f5b62b0a-bc67-41e4-9bd7-fe1 feb1cf549:8902c89 e476965f86ea47c7ea7d2c98673f8cb05/Sesja\%20I\%20spis\%20tre\%C5\%9Bci\%2 0KEP.pdf [date of entry: 25.12.1019].

Kiełczewski D., 2009, Ewolucja uprawomocniania wiedsy ekonomicznej a metodologia nauk. ekonomicznych, „Optimum. Studia Ekonomiczne”, nr 4(44), s. 3-13.

Kraciuk J., 2015, Nauki ekonomiczne wobec krysysów finansonych, „Journal of Modern Science", nr 2(25), s. 219-230.

Krugman P., 2009, How Did Economists Get it So Wrong?, „The New York Times”, 2 september.

Kvangraven I.H, Alves C., 2019, Heterodox Economics as a Positive Project: Revisiting the Debate, "ESRC GPID Research Network Working Paper". vol. 19, pp. 1-24.

Lawson T., 2006, The nature of heterodox economics, „Cambridge Journal of Economics”, vol. 30(4), pp. 483-505, DOI: $10.1093 / \mathrm{cje} /$ bei093.

Lee F., 2009, A History of Heterodox Economics: Challenging the mainstream in the twentieth century, Routledge, London. 
Mill J.S., 1965, The Principles of Political Economy with Some of Their Applications to Social Philosophy, [in:] The Collected Works of John Stuart Mill, University of Toronto Press, Routledge and Kegan Paul, Toronto, London.

Orrell D., 2017, Economyths: 11 Ways Ekocomics Get it Wrong, Icon Books, London.

Pomyśleć ekonomie od nowa. Pryeewodnik po glównych nurtach ekonomii heterodoksyjnej, 2018, Augustyński I. (red.), Wydawnictwo Ekonomiczne Heterodox, Poznań.

Robinson J., 2016, Szkice o ekonomii marksowskiej, Wydawnictwo Ekonomiczne Heterodox, Poznań.

Sedlacek T., 2012a, Ekonomia dobra $i$ zła, Studio Emka, Warszawa.

Sedlacek T., 2012b, Zmierz̨ch homo economicus, Studio Emka, Warszawa.

Stilwell F., 2019, From Economics to Political Economy: Contradictions, Challenge, and Change, "The American Journal of Economics and Sociology", vol. 78 (1), pp. 35-62, DOI: 10.1111/ajes.12259

Wells T.R., 2010, Why is Heterodox Economics a Joke?, http://www.philosophersbeard. org/2010/10/why-is-heterodox-economics-joke.html [date of entry: 12.06.2019].

Wilkin J., 2009, Czy ekonomia może być piekna? Rozważania o pržedmiocie i metodzie ekonomii, „Ekonomista”, nr 3, s. 295-313.

Wojtyna A., 2000, Ewolucja keynesizmu a gtówny nurt wspótczesnej ekonomii, Wydawnictwo Naukowe PWN, Warszawa.

Wojtyna A., 2019, Cyy w myniku obecnego kryzysu swiatowego zmienit sie zakres $i$ sposób uprawiania ekonomiit?, [w:] Ewolucja nauk ekonomicznych. Jedność a różnorodność, relacje do innych nauk, problemy klasyfikacyjne, Gorynia M. (red.), PAN, Warszawa.

Ząbkowicz A., 2019, Czyy istnieje ekonomia kapitalizmu?, „Optimum. Economic Studies”, nr 1(95), s. 3-18, DOI: 10.15290/oes.2019.01.95.01. 